\title{
THE INFLUENCE OF BEHAVIOR INTENTION, PERSONAL AUTONOMY, ACCESSIBILITY OF INFORMATION, AND SOCIAL SUPPORT ON THE COMPLIANCE OF THE USE OF PPE AT PT. PLN
}

\author{
Fanny Tri Cahyani ${ }^{1}$, Sri Widati ${ }^{1}$ \\ ${ }^{1}$ Department of Health Promotion and Behavioral Science, \\ Faculty of Public Health, Airlangga University, Surabaya, Indonesia \\ Correspondence Address: Fanny Tri Cahyani \\ E-mail: Fannytricahyani77@gmail.com
}

\begin{abstract}
The International Labor Organization states that more than 250,000,000 workplace accidents, more than 160,000,000 become ill because of hazards caused by the workplace, and 1,200,000 workers died due to their workplaces each year. Workplaces that have high levels of danger can cause harm to workers, and thus, companies as well. One effort to reduce the risk of danger is the use of Personal Protective Equipment (PPE). Compliance with the use of PPE is influenced by many factors. This study aims to analyze the influence of behavioral intention, personal autonomy, accessibility of information, and social support in complying with the use of PPE. This study was analytic observational and used the cross-sectional research design. The population of this research, amounting to 44 workers, were all employees at PT. PLN. The sample size was 41 samples selected using the simple random sampling method. This study shows (1) behavioral intention had no effect on compliance with the use of PPE (sig.= 0.581), and (2) personal autonomy had no effect on compliance with the use of PPE (sig. $=0.075$ ). Meanwhile, (3) social support had no effect on compliance with the use of PPE (sig. = 0.575). However, accessibility of information affected the use of PPE (sig. = 0.042). To maintain compliance with the use of PPE, researchers suggest to continue health promotion, conduct monitors, and implement a reward and punishment system for workers.
\end{abstract}

Keywords: accessibility of information, behavior intention, personal autonomy, personal protective equipment, social support

\begin{abstract}
ABSTRAK
Organisasi Perburuhan Internasional (ILO) menyatakan bahwa lebih dari 250.000.000 kecelakaan di tempat kerja dan lebih dari 160.000.000 menjadi sakit karena bahaya yang disebabkan di tempat kerja pada setiap tahunnya. Sedangkan pekerja yang meninggal diakibatkan karena tempat kerja terdapat jumlah 1.200 .000 pekerja. Tempat kerja yang memiliki tingkat bahaya yang tinggi dapat menyebabkan kerugian pada pekerja dan perusahaan. Salah satu upaya untuk mengurangi risiko dari bahaya yaitu pemakaian Alat Pelindung Diri (APD). Kepatuhan pemakaian APD dipengaruhi oleh banyak faktor. Penelitian ini bertujuan untuk menganaisis pengaruh niat perilaku, otonomi pribadi, aksesibilitas informasi, dan dukungan social terhadap kepatuhan pemakaian APD. Jenis penelitian ini yaitu observasional analitik dengan desain penelitian potong-lintang. Populasi penelitian ini yaitu seluruh pekerja di PT. PLN sejumlah 44 pekerja. Besar sampel yaitu 41 sampel dan cara pengambilan sampel yang digunakan yaitu pengambilan acak sederhana. Hasil menunjukkan (1) niat perilaku tidak berpengaruh terhadap kepatuhan pemakaian APD (sig.= 0,581), dan (2) otonomi pribadi tidak berpengaruh terhadap kepatuhan pemakaian APD (sig. = 0,075). Sedangkan, (3) dukungan social tidak berpengaruh terhadap kepatuhan pemakaian APD (sig. =0,575). Namun, aksesibilitas informasi berpengaruh terhadap kepatuhan pemakaian APD (sig. $=0,042)$. Dalam upaya mempertahankan kepatuhan pemakaian APD, peneliti menyarankan untuk mempertahankan promosi kesehatan, mengadakan monitoring dan menerapkan adanya sistem reward and punishment untuk tenaga kerja.
\end{abstract}

Kata kunci: aksesibilitas informasi, niat perilaku, otonomi pribadi, alat pelindung diri, dukungan sosial

\section{INTRODUCTION}

Advanced modern technology started to emerge, allowing industries to have more efficient production process. This also allows manpower to access more practical work. High quality/grade products and services produced by industries will continuously be supported by modern production processes using high-tech 
materials and equipment. However, if the utilization of the technology cannot be handled correctly, it might pose a risk of endangering occupational health and safety, causing accidents in their use. Good worker behavior is also believed to be an essential element to reduce work accidents (Puspitasari, Prabandari and Budiharjo, 2018).

Occupational health and safety are considered as the thought or effort to guarante wholeness and perfection both spiritually and physically. With the security of occupational health and safety, employees are expected to be able to accomplish work in comfortable and safe conditions as well as achieve high levels of health, work power, and physical endurance (Redjeki, 2016). Occupational health and safety might become the main focus in all sectors of work. Furthermore, work, health, and safety are considered as the benchmark for every company. When a company has a high accident rate due to work, it can be said that the company has low-risk management (Tagueha, Mangare and Arsjad, 2018). This situation might generate a low rating for the company.

The International Labor Organization (ILO) states that more than 250,000,000 accidents and over 160,000,000 workers became sick due to hazards that exist in the workplace each year, while 1,200,000 workers died due to their workplace conditions (International Labour Organization, 2013). According to the Social Insurance Administration Organization (BPJS) Employment, it is reported that the total work accidents in 2015 were 110,285 cases, while in 2016, as many as 105,182 cases occurred. In a year, it is noted that there was a decrease of $4.6 \%$. However, as of August 2017, there were 80,392 cases of work accident (Social Insurance Administration Organization (BPJS) Employment, 2016).
The work environment might be able to influence employee behaviors and attitudes. When an employee feels that the work environment is comfortable, it is highly possible that there will be some indirect increase in employee morale and performance. Hence, it is concluded that the work environment plays a vital role in influencing employee behavior and attitudes (Ayu and Krisnani, 2018). A safe and healthy workplace will likely increase employee effectiveness allowing them to work efficiently. However, a workplace always has some hazards that may cause harm to workers and, in turn, the company. Complications that may happen include loss of property, injury, disability, and even fatality (International Labour Organization, 2013). Work environment hazards are defined as various potential hazards caused by working environment conditions, including biological, chemical, physical, or other employee environmental conditions (Dewanti and colleagues, 2018).

A system in a company is expected to include input, output, and production processes. The production process is believed to become more manageable with the presence of high-tech machinery and various chemicals to get quality services or products. However, these upgrades may increase some risks, for example occupational diseases or work-related accidents. Therefore, good employee behavior remains crucial to reduce risk. One possible effort to reduce the risk of hazard is the use of Personal Protective Equipment (PPE). The definition of PPE is having complete mandatory safety equipment imposed when carrying out work, according to the risks and dangers, to maintain the safety and health of workers and others (Redjeki, 2016).

A report by Zahara, Effendi and Khairani (2017) states that there was noncompliance towards the use of PPE by $54.7 \%$, with the remaining $45.3 \%$ of 
respondents complying. One knowledgeable employee was obedient due to a work accident. According to Astiningsih, Kurniawan, and Suroto (2018), 54\% of project construction workers did not comply with wearing PPE, while the other $46 \%$ did.

Obedience refers to a form of someone's behavior. Behavior can be defined as a form of individual response to an object or objects that are found around it (Notoatmodjo, 2003). There are two kinds of work behavior, which are unsafety and safety behavior. Unsafety behavior indicates behavior that has a risk of work accidents against employees. These incidents occur because unsafety is high. The accidents usually occur as a result of the employees not wearing PPE although it has been provided at the workplace by the company. Safety behavior denotes behavior that lowers the risks of work accidents. For example, employees wear PPE, such as special shoes, earplugs, and special helmets. As a result, employees will be able to do work safely (Ayu, Sunaryo and Dewi, 2017).

A person's behavior is believed to be very challenging to change, mainly when the individual performs identical behavior continuously for an extended period. Altering a person's behavior may take a long time as it has to be approached as often as possible due to the number of past exposures received by the individual. Many factors might affect an individual's healthy behavior since behavior is a result of the internal and external influences (Notoatmodjo, 2012).

According to the Activity-based costing ( $\mathrm{ABC}$ ) concept, an individual's behavior can be triggered by a series of antecedent events (everything that existed before the behavior was formed) and followed by a consequence (an event that is always present in every behavior) that will cause the behavior to repeat. The $\mathrm{ABC}$ concept allows the analysis of the various ways behavior changes by ensuring the presence of relevant antecedent factors and the consequences of supporting the behavior according to what is expected. Antecedents refer to factors that exist before the formation of behavior and acts as a trigger for a behavior. However, antecedents alone cannot guarantee that behavior is able to persist from time to time, thus requiring the presence of consequences (Fleming and Lardner, 2002).

In Snehandu B. Kar's behavior theory, the notion of healthy behavior can be described as a function of an individual's intention to take action, social support, information availability, personal autonomy, and supportive situations for action. The individual's intention in acting (behavior intention) is the willingness to take action according to the objects or stimuli outside themselves. Social support is defined as support from surrounding people, considering an individual's behavior requires legitimisation and recognition by others. The availability of information (accessibility of information) signifies the existence of information and access to health facilities. Personal autonomy means the freedom of individuals to make decisions without pressure from outside parties. The situation that supports (action situation) is where there is the right condition to maintain a behavior (Notoatmodjo, 2012). The factors that have been mentioned in the theory of Snehandu B. Kar can be classified as an antecedent factor in the $\mathrm{ABC}$ theory.

The importance of antecedent factors in initiating the formation of behavior generates researchers' interest in conducting studies related to it. Therefore, this study aims to analyze the influence of behavioral intention, personal autonomy, accessibility of information, and social support on the compliance of the use of PPE on the State Electricity Company (PT. PLN).

\section{METHODS}


This study used a qualitative, observational analytic method. Analytic observational research analyzes data obtained to look for a relationship of research variables (Santosa, 2008). The data were collected using the cross-sectional approach allowing the research variables to be measured and collected at once. This study was conducted in PT. PLN Surabaya in July 2019.

Fourty four employees of PT.PLN under Work Under Tension (PDKB) team were selected as the population of the study. The inclusion criteria for the participants were being a male worker, working in the field, and was a permanent worker of PT. PLN. As many as 41 samples were successfully obtained throough simple random sampling. Simple random sampling is a research sampling technique that promotes fairness in sample selection so that members of the population receive a fair opportunity. (Triyono, 2003).

The independent variables of the study were behavior intention, personal autonomy, accessibility of information, and social support. On the other hand, compliance with the use of PPE acted as the dependent variable. The data were collected using questionnaires then later analyzed with a statistical test called the chi-square test. Ethical approval for this study was obtained from the Research Ethics Committee of Faculty of Dental Medicine, Universitas Airlangga with the certification number 320/HRECC.FODM/VI/2019.

\section{RESULTS}

\section{General Overview of PT. PLN PDKB Team}

PT. PLN is the implementing unit under State-Owned Enterprises (BUMN), located at J1. Embong Trengguli No. 19-21 Embong Kaliasin, Genteng, Surabaya. Its vision is to be a continuously growing trusted and superior world-class company which values human potential. PT. PLN stands for (1) inventing the electricity business and other related fields, (2) orientating on customer satisfaction, (3) its shareholders and company members, (4) improving the quality of life of the community by making electricity for the media, (5) striving for electricity growth in economic activities, and (5) conducting business activities with environmental considerations.

The PDKB Team, a work unit at PT. PLN, consists of workers that are preconditioned to work under pressure. The PDKB team was formed in 1993, in Indonesia, but was finally set up in Surabaya in 1996. The PDKB team is in charge of carrying out maintenance work, expanding the systems, handling disturbances, and repairing disruptions that occur in the community.

The PDKB teamwork system of PT. PLN has three working systems, which are distance system, potential method, and direct touch or direct contact method. The distance system is executed using insulated poles, where workers are not allowed to come into direct contact with electricity sources. The potential system is when workers have light contact with electricity, while the direct touch system requires the workers to directly handle electricity while still using PPE.

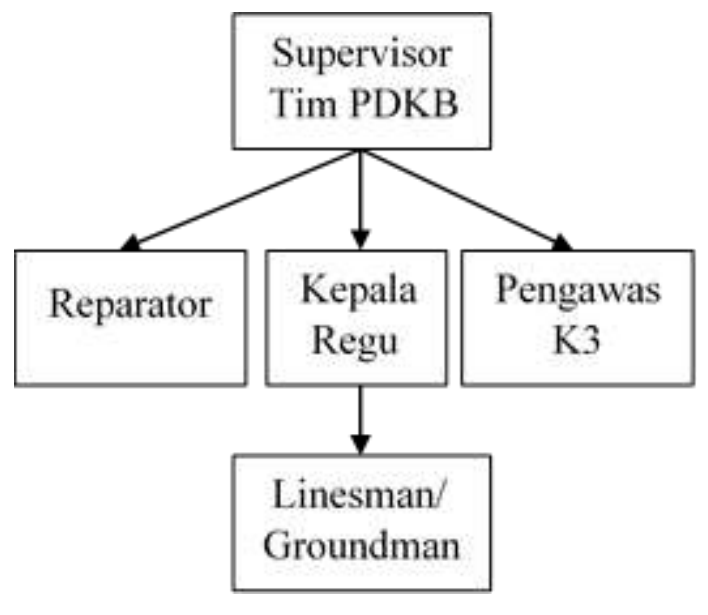


Chart 1. Organizational Structure of PT. PLN PDKB Team

Based on Chart 1, the PDKB team is structured by levels, each with different tasks. The reparator has to manage the server, make schedules, and determine what methods will be used by workers. The head of the team (Kepala Regu) has the role of leading and controlling workers in the field, taking full responsibility from the beginning until the end of the work. OHS supervisors (Pengawas K3) have the same task as supervisors which is ensuring workers are in healthy and safe conditions. Linesman or Groundman has the duties as executor and assistant executor, where Linesman work up high and Groundsman work on the ground.

\section{Overview of Respondent Characteristics Based on Education Level}

The education level of workers refers to formal education completed by employees who are willing to become respondents. Following is the frequency distribution of respondent characteristics based on education level.

Table 1. Frequency Distribution of Respondent Characteristics Based on Education Level

\begin{tabular}{lcc}
\hline \multirow{2}{*}{\multicolumn{1}{c}{ Education Level }} & \multicolumn{2}{c}{ Total } \\
\cline { 2 - 3 } & $\mathbf{n}$ & \% \\
\hline SMA/ SMK (High School) & 30 & 7.2 \\
\hline Diploma & 4 & 9.8 \\
\hline Bachelor & 7 & 17.1 \\
\hline Total & 41 & 100 \\
\hline
\end{tabular}

Table $\quad 1$ shows $\quad 73.2 \% \quad$ (30 respondents) have graduted from high school/vocational education, and 9.8\% (4 respondents) have diplomas or equivalent certificates; as many as $17.1 \%$ (7 respondents) have bachelor's degree. Therefore, it can be concluded that the majority of workers in the PDKB Team of
PT. PLN are of high school/vocational education level.

\section{Overview of Behavior Intention}

Behavior intention may refer to the desire of workers to the use of PPE due to stimulation from the surrounding environment. The identification of behavior intention can be divided into two groups: respondents whose behavior intention is good and those who are sufficient (fair). The following is the frequency distribution of the respondent's intended behavior.

Table 2. Frequency Distribution of Respondent Behavior Intention

\begin{tabular}{lcc}
\hline \multirow{2}{*}{ Behavior Intention } & \multicolumn{2}{c}{ Total } \\
\cline { 2 - 3 } & n & \% \\
\hline Good & 35 & 85.4 \\
\hline Fair & 6 & 14.6 \\
\hline Total & 41 & 100 \\
\hline
\end{tabular}

Table 2 shows $85.4 \% \quad$ (35 respondents) had good behavioral intention, and only $14.6 \%$ (6 respondents) had sufficient behavioral intention. Therefore, it can be concluded that a majority of respondents had good behavioral intentions and were in compliance with the use of PPE when working.

\section{Overview of Personal Autonomy}

Personal autonomy refers to the freedom to make decisions in the form of self-control in using PPE. It is differentiated into two types, namely respondents whose personal autonomy is good and sufficient (fair). Frequency of the respondents' personal autonomy is shown in Table 3.

Table 3. Frequency Distribution of Respondents' Personal Autonomy

\begin{tabular}{lcc}
\hline \multirow{2}{*}{ Personal Autonomy } & \multicolumn{2}{c}{ Total } \\
\cline { 2 - 3 } & n & \% \\
\hline Good & 40 & 97.6 \\
\hline
\end{tabular}




\begin{tabular}{lcc}
\hline Fair & 1 & 2.4 \\
\hline Total & 41 & 100 \\
\hline
\end{tabular}

Table 3 presents $97.6 \% \quad(40$ respondents) had good personal autonomy, and $2.4 \%$ (1 respondent) was sufficient. The conclusion that can be drawn is that a majority of the respondents have good personal autonomy related to compliance with the utilization of PPE at work.

\section{Overview of Accessibility of Information}

Accessibility of information is the perspective on availability/attainability of information about protective equipment, obtained directly or indirectly by workers. Accessibility of information can be identifed into two groups: respondents who sense information related to PPE and those who sense its absence. The following is a frequency distribution of the accessibility of information.

Table 4. Frequency Distribution of Accessibility of Information

\begin{tabular}{lcc}
\hline \multicolumn{2}{c}{$\begin{array}{c}\text { Accessibility of } \\
\text { Information }\end{array}$} & \multicolumn{2}{c}{ Total } \\
\cline { 2 - 3 } & n & \% \\
\hline Yes & 24 & 58.5 \\
\hline No & 17 & 41.5 \\
\hline Total & 41 & 100 \\
\hline
\end{tabular}

Table 4 shows that $58.5 \% \quad(24$ respondents) acknowledged that there was information related to PPE, while $41.5 \%$ (17 respondents) stated that there was not. Therefore, it can be inferred that some respondents did not receive information related to PPE.

\section{Overview of Social Support}

Social support can be acquired as encouragement from close friends, the surrounding environment, and even other workers regarding the use of PPE. The identification of social support could be divided into good or sufficient (fair) social support. The following is a frequency distribution for social support.

Table 5. Frequency Distribution of Social Support

\begin{tabular}{lcc}
\hline \multirow{2}{*}{ Social Support } & \multicolumn{2}{c}{ Total } \\
\cline { 2 - 3 } & n & \% \\
\hline Baik & 30 & 73.2 \\
\hline Cukup & 11 & 26.8 \\
\hline Total & 41 & 100 \\
\hline
\end{tabular}

It can be seen in Table 5 that as many as or $73.2 \%$ (30 respondents) acknowledged that there was a good amount of social support, and the other $26.8 \%$ (11 respondents) agreed it was sufficient. In conclusion, most respondents acknowledged they have received satisfying social support.

\section{Overview of the Level of Compliance in the Utilization of PPE}

Compliance with the utilization of PPE is a form of employee behavior related to wearing PPE that is required by the company. Identification of compliance is divided into two groups: respondents who comply with or do not comply with the utilization of PPE. Following is the frequency distribution of compliance with the use of personal protective equipment.

Table 6. Frequency Distribution of the Compliance Level in the Utilization of PPE

\begin{tabular}{lcc}
\hline \multirow{2}{*}{ Obidience } & \multicolumn{2}{c}{ Total } \\
\cline { 2 - 3 } & n & \% \\
\hline Obey & 31 & 75.6 \\
\hline Disobey & 10 & 24.4 \\
\hline Total & 41 & 100 \\
\hline
\end{tabular}

Based on Table 6, 75.6\% (31 respondents) had complied to wearing personal protective equipment, while $24.4 \%$ (10 respondents) were not wearing it when working. It can be concluded that the majority of respondents had complied with 
wearing personal protective equipment while working.

\section{The Effect of Behavior Intention on Compliance with the Utilization of PPE}

The following is the results of analysis of the effect of behavior intention on the application of PPE.

Table 7. The Effect of Behavior Intention on Compliance with the Utilization of PPE

\begin{tabular}{ccccccc}
\hline \multirow{2}{*}{$\begin{array}{c}\text { Behavior } \\
\text { Intention }\end{array}$} & \multicolumn{3}{c}{$\begin{array}{c}\text { Compliance with PPE } \\
\text { Usage }\end{array}$} & \multirow{2}{*}{ Total } \\
\cline { 2 - 6 } & \multicolumn{2}{c}{ Obey } & \multicolumn{2}{c}{ Disobey } & & \\
\cline { 2 - 6 } & $\mathbf{n}$ & $\mathbf{\%}$ & $\mathbf{n}$ & $\mathbf{\%}$ & $\mathbf{n}$ & $\mathbf{\%}$ \\
\hline Good & 27 & 77.2 & 8 & 22.8 & 35 & 100 \\
\hline Fair & 4 & 66.7 & 2 & 33.3 & 6 & 100 \\
\hline Total & 31 & 75.6 & 10 & 24.4 & 41 & 100 \\
\hline \multicolumn{6}{c}{ Sig. $=0.581$} \\
\hline
\end{tabular}

It can be inferred from Table 7 that $77.2 \%$ (27 respondents) had good behavioral intentions and were compliant with the use of PPE, while the remaining 66.7\%. (4 respondents) had sufficient behavioral intentions. Although $22.8 \%$ (8 respondents) had good behavioral intentions and $33.3 \%$ (2 respondents) were sufficient, they were not compliant with the use of PPE.

The results of the statistical test analysis had shown that there was not any influence of behavior intention on compliance with the utilization of PPE (sig. $=(0.581)>0.05)$.

\section{The Effect of Personal Autonomy on Compliance with the Utilization of PPE}

Table 8 has shown that $77.5 \%$ (31 respondents) has good personal autonomy and were compliant with the use of PPE, while $22.5 \%$ (9 respondents) were not compliant with the use of PPE. On the other hand, only one respondent had sufficient personal autonomy and was not compliant with the use of PPE.
From the results of the study, it can be noted that there was no influence of personal autonomy on the compliance with the utilization of PPE (sig. $=(0.075)>0.05)$. The results of analysis of the effect of personal autonomy on the application of PPE can be seen in the table below.

Table 8. The Effect of Personal Autonomy on Compliance with the Utilization of PPE

\begin{tabular}{ccccccc}
\hline \multirow{2}{*}{$\begin{array}{c}\text { Personal } \\
\text { Autonomy }\end{array}$} & \multicolumn{3}{c}{$\begin{array}{c}\text { Compliance with PPE } \\
\text { Usage }\end{array}$} & \multirow{2}{*}{ Total } \\
\cline { 2 - 6 } & \multicolumn{2}{c}{ Obey } & \multicolumn{2}{c}{ Obey } & & \\
\cline { 2 - 6 } & $\mathbf{n}$ & $\mathbf{\%}$ & $\mathbf{n}$ & $\mathbf{\%}$ & $\mathbf{n}$ & $\%$ \\
\hline Good & 31 & 77.5 & 9 & 22.5 & 40 & 100 \\
\hline Fair & 0 & 0,0 & 1 & 100 & 1 & 100 \\
\hline Total & 31 & 75.6 & 10 & 24.4 & 41 & 100 \\
\hline \multicolumn{6}{c}{ Sig. $=0.075$} \\
\hline
\end{tabular}

The Effect of Accessibility of Information on Compliance with the Utilization of PPE

The following is the results of analysis of the effect of accessibility of information on the application of PPE.

Table 9. The Effect of Accessibility of Information on Compliance with the Utilization of PPE

\begin{tabular}{|c|c|c|c|c|c|c|}
\hline \multirow{3}{*}{$\begin{array}{c}\text { Accessibi } \\
\text { lity of } \\
\text { Informat } \\
\text { ion }\end{array}$} & \multicolumn{4}{|c|}{$\begin{array}{c}\text { Compliance with PPE } \\
\text { Usage }\end{array}$} & \multirow{2}{*}{\multicolumn{2}{|c|}{ Total }} \\
\hline & \multicolumn{2}{|c|}{ Obey } & \multicolumn{2}{|c|}{ Disobey } & & \\
\hline & $\mathrm{n}$ & $\%$ & $\mathrm{n}$ & $\%$ & $\mathbf{n}$ & $\%$ \\
\hline Yes & 31 & 77.5 & 9 & 22.5 & 40 & 100 \\
\hline No & 0 & 0.0 & 1 & 100 & 1 & 100 \\
\hline Total & 31 & 75.6 & 10 & 24.4 & 41 & 100 \\
\hline \multicolumn{7}{|c|}{ Sig. $=0.042$} \\
\hline & & & .10 & & & \\
\hline
\end{tabular}

Table 9 shows $\quad 77.5 \% \quad$ (31 respondents) had real access to the PPE information and were compliant with the use of PPE, while $22.5 \%$ (9 respondents) were not. On the other hand, only one respondent did not receive information related to PPE and was not compliant with the use of PPE. 
From the results of the study, it can be concluded that there was an influence of the accessibility of information with the compliance the utilization of PPE (sig. = $(0.042)>0.05)$. B-value of 0.104 refers to the existence of information would likely influence a worker 0.104 times more compliant with the utlizaiton of PPE than the absence of information.

\section{The Effect of Social Support on Compliance with the Utilization of PPE}

The results of analysis of the effect of social support on the application of PPE can be seen in Table 10.

Table 10. The Effect of Social Support on Compliance with the Utilization of PPE

\begin{tabular}{ccccccc}
\hline \multirow{3}{*}{$\begin{array}{c}\text { Social } \\
\text { Support }\end{array}$} & \multicolumn{4}{c}{ Compliance with PPE } & \multirow{2}{*}{ Total } \\
\cline { 2 - 6 } & \multicolumn{2}{c}{ Obey } & \multicolumn{1}{c}{ Disobey } & & \\
\cline { 2 - 6 } & $\mathbf{n}$ & $\mathbf{\%}$ & $\mathbf{n}$ & $\mathbf{\%}$ & $\mathbf{n}$ & $\mathbf{\%}$ \\
\hline Good & 22 & 73.3 & 8 & 26.7 & 30 & 100 \\
\hline Fair & 9 & 81.8 & 2 & 18.2 & 11 & 100 \\
\hline Total & 31 & 75.6 & 10 & 24.4 & 41 & 100 \\
\hline \multicolumn{6}{c}{ Sig. $=0.575$} \\
\hline
\end{tabular}

Table $\quad 10 \quad$ shows $\quad 73.3 \% \quad$ (22 respondents) had good social support, and $81.8 \%$ (9 respondents) had sufficient social support. They also shared the same compliance with the use of PPE. On the other hand, $26.7 \%$ (8 respondents) with good social support and $18.2 \%$ (2 respondents) with sufficient social support were not compliant with the use of PPE.

The results of the statistical test analysis shows that there was no effect of social support on the compliance with the use of PPE $($ sig. $=(0.575)>0.05)$.

\section{DISCUSSION}

The Effect of Behavior Intention on Compliance with the Utilization of PPE
According to the data analysis, the majority of PT. PLN PDKB team have good behavior intentions and complies with the use of PPE. Statistical tests show that there was no effect of behavioral intention on compliance with the utilization of PPE.

However, these results are not supported by Hartoni and Riana (2015) who believed that intention was significantly influenced by the attitude of each individual. Hence, the increasing intention of individuals will improve the intention of employees to behave. This study, however, is not in line with research by Pebriyanti and Azizah (2018) that behavior was the main factor to compliance with the use of PPE in farmers. Behavior is formed from two main factors, namely knowledge and attitude, and other factors including the willingness of farmers to use PPE.

Individual intention to form a particular behavior might be influenced by external factors. PT. PLN PDKB team may have the intention to utilize PPE because they acknowledge the consequences if not worn. However, some workers tend to be apathetic, primarily, when they accomplish work that might be considered standard and finished in a short period of time. Thus, the intention they originally had of wearing PPE was neglected.

However, occupied intention might not affect compliance with PPE usage. This situation is likely caused by the level of selfawareness of each individual. The lower the level of individual awareness of the importance of using PPE, the lower number of workers utilizing PPE may be. Besides, individuals also cannot behave based on intention if they have no control over their own behavior. It means that intention may be the only consideration, though behavior control will determine it further.

The Effect of Personal Autonomy on Compliance with the Utilization of PPE 
The findings show that the majority of PT. PLN PDKB employees have good personal autonomy and comply with the use of PPE. It is confirmed through the statistical test that there was no personal autonomy effect on compliance with PPE usage.

These findings are consistent with research by Fitriani, Dharmawansyah and Abadi (2015) that state that there was no existence of personal autonomy influence on compliance with prescription writing according to the formulary. However, this study is contrary to that of Malikah (2017), who found that high self-control caused high adherence in the adolescent students of the Wahid Hasyim Islamic Senior High School.

Every worker possess personal autonomy. Workers may have received direction and have been provided with PPE, but the decision to wear it depends on each individual. Workers tend to underestimate the risks they encounter because they assume the work is effortless daily duty. Thus, they decide to not wear PPE or even deliberately not carry it with them.

Every individual might own personal autonomy, but not all individuals might be able to make decisions based on the requirements. This condition is likely due to differences in individual education levels. A lower level of education limits a person, therefore, making the individual easily influenced. It may result in the decision making process to be hindered, in this case regarding the compliance with the utilization of PPE. On the contrary, an individual who has a higher level of education might be able to settle on various deliberations that are adequate without any influence from others.

\section{The Effect of Accessibility of Information on Compliance with the Utilization of PPE}

The findings indicate that the majority of PT. PLN PDKB employees acknowledge that they have acquired information related to PPE and have complied with its use. It is supported by the statistical tests, indicating that there was an effect of the accessibility of information on compliance with PPE usage.

This study is corroborated by Dewi, Ekawati and Kurniawan's research (2016), showing that most employees did not use PPE when working due to a lack of information. The previous research found that socialization was not given to all employees, only the head of the team and the head of the department. These findings also reflect those of Saragih, Kurniawan and Ekawati's (2016), finding that workers did not routinely use PPE. This situation might be possible if there is no additional socialization given to the mass, but only to particular workers causing a lack of information. Moreover, this result is also supported by previous research (Mahendra, Kurniawan and Suroto, 2015). The availability of information about PPE at PT. PLN is adequate to facilitate the behavior of using PPE.

Accessibility of information can be the form of direct or indirect delivery. Direct delivery could be counselling and outreach, while indirect delivery includes campaigns through posters or slogans.

\section{The Effect of Social Support on Compliance with the Utilization of PPE}

Based on the findings, the majority of PT. PLN PDKB employees had good social support and had complied with the use of PPE. Statistical tests show that there was no influence of social support on compliance with use of PPE. This study is in accordance with the research conducted by Putra, Setyaningsih and Jayanti (2017), which shows that there was no influence of social support with compliance of the use of PPE on Process Safety Information (PSI) workers in area X of PT. Y. Likewise, this research is also consistent with research by Prakoso and 
Fatah (2017) who found that most of the employee's intention to behave safely was accompanied by unfavorable social support.

However, the outcome is contrary to that of Puji, Kurniawan and, Jayanti's research (2017), which found a correlation between social support and compliance in the utilization of PPE. The study is also not in line with research conducted by Sumarna, Naiem, and Russeng (2013), which concluded that there was a relationship between social environment and the imposition of gloves on printing operators in the city of Makassar. Chairunnisa (2018) also refers to the person shows a significant correlation of social support and compliance with the utilization of PPE in PT Asam Jawa workshop employees.

Social support might be in the form of support shown by colleagues or by superiors. A possible explanation for the difference in the results might be caused by the PT. PLN PDKB employees receiving proper PPE including individual lockers located in the office area. Some teams operate in the field, while the others have desk jobs. As a result, colleagues lack of concerns to remind one another of using PPE. Furthermore, inadequate monitoring routines from superiors related to the use of PPE might cause a feeling of neglection among the employees, eventually becoming ignorant.

\section{CONCLUSION}

In general, it seems that the majority of PT. PLN PDKB employees have obtained high school or vocational education. The employees complied with wearing PPE at work, had good behavior intentions, had satisfying personal autonomy, recieved information related to PPE, and had enough social support. The results of the study indicate that behavior intention, personal autonomy, and social support did not affect the compliance of the use of PPE, while the accessibility of information did influence the compliance of use.

To maintain compliance with the use of PPE, this study suggests that health promotion regarding can be delivered by adminsitering posters placed in strategic noticeable places. Monitoring the use of PPE and implementing a reward/punishment system for workers can also be performed to increase the awareness of using PPE. Rewards can be awarded to compliant workers, and punishment can be delivered to employees who do not comply.

\section{REFERENCES}

Astiningsih, H., Kurniawan, B. and Suroto (2018) 'Hubungan Penerapan Program K3 Terhadap Kepatuhan Penggunaan APD pada Pekerja Konstruksi di Pembangunan Gedung Parkir Bandara Ahmad Yani Semarang', Jurnal Kesehatan Masyarakat, 6(4), pp. 300-308.

Ayu, D. S. and Krisnani, H. (2018) 'Pengaruh Lingkungan Kerja Sehingga Menghasilkan Suatu yang Erat antar Petugas K3L UNPAD', Jurnal Pekerjaan Sosial, 1, pp. 1626. doi: https://doi.org/10.24198/focus.v1i2.1 8252.g8547.

Ayu, F., Sunaryo, M. and Dewi, R. G. A. I. (2017) 'Penyuluhan Kesehatan Tentang Pentingnya Berperilaku Sehat dan Selamat di Jalan Raya pada Pelajar SMK Farmasi Surabaya', Community Development Journal, 1(1), pp. 16-19.

Social Insurance Administration Organization (BPJS) Employment .2016. Jumlah Kecelakaan Kerja di Indonesia Masih Tinggi.

Chairunnisa, Y. (2018) Analisis Faktor yang Berhubungan dengan Kepatuhan Menggunakan APD ( APD) pada Pekerja Bagian Bengkel di 
Perkebunan Kelapa Sawit PT Asam Jawa Labuhanbatu Selatan Tahun 2018. Universitas Sumatera Utara.

Dewanti, N. A. Y. et al. (2018) 'Faktor Risiko Bahaya Tempat Kerja dan Lingkungan Rumah terhadap Kesehatan Home-based Worker di Kota Semarang', Jurnal Kesehatan Lingkungan Indonesia, 17(1), pp. 52-58. doi: 10.14710/jkli.17.1.52-58.

Dewi, faddila P., Ekawati and Kurniawan, B. (2016) 'Analisis Kepatuhan Karyawan terhadap Penggunaan Alat Pelindung Diri (APD) di PT. Kebon Agung Unit PG. Trangkil Pati', Jurnal Kesehatan Masyarakat, 4(1), pp. 304-311.

Fitriani, S., Dharmawansyah and Abadi, M. Y. (2015) 'Faktor-faktor yang Mempengaruhi Kepatuhan Dokter dalam Menuliskan Resep sesuai Formularium di RSUP Dr, Wahudin Sudirohusodo', Universitas Hasanuddin.

Fleming, M. and Lardner, R. (2002) Strategies to Promote Safe Behaviour as Part of a Health and Safety Management System. Norwich: Health \& Safety Executive. Hartoni, I. G. P. O. and Riana, I. G. (2015) 'Sikap, Norma Subjektif dan Kontrol Perilaku pada Implementasi Keselamatan Kerja: Dampaknya Terhadap Intention to Comply', EJurnal Ekonomi dan Bisnis Udayana, 4(4), pp. 243-264.

International Labour Organization (2013) Keselamatan dan Kesehatan Kerja Sarana untuk Produktivitas. 1 st. Jakarta: SCORE.

Mahendra, R., Kurniawan, B. and Suroto (2015) 'Faktor-faktor yang Berhubungan dengan Perilaku Penggunaan Alat Pelindung Diri (APD) pada Pekerjaan Ketinggian di PT. X', Jurnal Kesehatan Masyarakat, 3(3), pp. 572-581.
Malikah, S. S. (2017) Hubungan antara Kontrol Diri dengan Kepatuhan terhadap Peraturan pada Santri Remaja. Universitas Islam Negeri Maulana Malik Ibrahim Malang.

Notoatmodjo, S. (2003) Pendidikan dan Perilaku Kesehatan. Jakarta: Rineka Cipta.

Notoatmodjo, S. (2012) Prinsip-prinsip Dasar Ilmu Kesehatan Masyarakat. Jakarta: Rineka Cipta.

Pebriyanti, D. O. and Azizah, L. N. (2018) 'Faktor-faktor yang Berhubungan dengan Kepatuhan Penggunaan Alat Pelindung Diri (APD) pada Petani: : Literatur Review', in 1st Annual Agricultural Health Nursing Seminar: Update Management and Prevention Disease Related to Agricultural Activities Clinical Setting. Jember: Universitas Jember, pp. 80-84.

Prakoso, G. D. and Fatah, M. Z. (2017) 'Analisis Pengaruh Sikap, Kontrol Perilaku dan Norma Subjektif Terhadap Perilaku Safety', Jurnal Promkes, 5(2), pp. 193-204. doi: http://dx.doi.org/10.20473/jpk.V5.I2. 2017.193-204.

Puji, A. D., Kurniawan, B. and Jayanti, S. (2017) 'Faktor-faktor yang Berhubungan dengan Kepatuhan Penggunaan APD pada Pekerja Rekanan (PT. X) di PT Indonesia Power Up Semarang', Jurnal Kesehatan Masyarakat, 5(5), pp. 2031.

Puspitasari, H. D. R., Prabandari, Y. S. and Budiharjo, S. (2018) Hubungan antara Komitmen Manajemen , Perilaku K3 dan Shift Kerja dengan Kejadian Kecelakaan Kerja pada Pekerja di RSUD Kanjuruhan Kepanjen Kabupaten Malang. Yogyakarta.

Putra, D. Y., Setyaningsih, Y. and Jayanti, S. (2017) 'Faktor-faktor yang 
Berhubungan dengan Praktik 10.30604/jika.v2i2.60.

epatuhan Pekerja terhadap Process Safety Information (PSI) di Area X PT. Y', Jurnal Kesehatan Masyarakat, 5(5).

Redjeki, S. (2016) Modul Bahan Ajar Cetak Farmasi: Kesehatan dan Keselamatan Kerja. Jakarta: Badan Pengembangan dan Pemberdayaan Sumber Daya Manusia Kesehatan.

Santosa, S. (2008) 'Bab III Rancangan Penelitian', in Metodologi Penelitian Biomedis, pp. 43-60.

Saragih, V. I., Kurniawan, B. and Ekawati (2016) 'Analisis Kepatuhan Pekerja terhadap Penggunaan Alat Pelindung Diri (APD) (Studi Kasus Area Produksi di PT. X)', Jurnal Kesehatan Masyarakat, 4(4), pp. 747-755.

Sumarna, D. P., Naiem, M. F. and Russeng, S. S. (2013) 'Determinan Penggunaan Alat Pelindung Diri (APD) pada Karyawan Percetakan di Kota Makassar', Universitas Hasanuddin.

Tagueha, W. P., Mangare, J. B. and Arsjad, T. T. (2018) 'Manajemen Risiko Keselamatan dan Kesehatan Kerja (K3) pada Proyek Konstruksi (Studi Kasus: Pembangunan Gedung Laboratorium Fakultas Teknik Unstrat)', Jurnal Sipil Statik, 6(11), pp. 907-916.

Triyono (2003) 'Teknik Sampling dalam Penelitian', Penataran Analisis Data Penelitian bagi Dosen PTS Kopertis $X I$. doi: 10.13140/RG.2.2.19674.24003.

Zahara, R. A., Effendi, S. U. and Khairani, N. (2017) 'Kepatuhan Menggunakan Alat Pelindung Diri ( APD ) Ditinjau dari Pengetahuan dan Perilaku pada Petugas Instalasi Pemeliharaan Sarana Dan Prasarana Rumah Sakit ( IPSRS )', Aisyah: Jurnal Ilmu Kesehatan, 2(2), pp. 153-158. doi: 